\title{
Analysis of Knowledge, Attitude, Employee Action in the Use of Personal Protective Equipment (PPE) with Work Accidents
}

\begin{abstract}
Nur Aini Fatimah, Nurwijayanti, Siti Farida

STIKes Satria Bhakti Nganjuk, Indonesia

Email:

rani34@stikessatriabhakti.ac.id

One of the causes of workplace accidents is the lack of awareness of the use of personal protective equipment for workers in the workplace. One of the ways to prevent workplace accidents is to require personal protective equipment (PPE) that meets the requirements, namely: comfort in use, does not hinder the work process, and provides effective protection against types of hazards. The objective of this research was to analyze the knowledge, attitudes, actions of employees in the use of personal protective equipment with work accidents at PT. Bisi International, Tbk., Tulungrejo Pare Kediri. The design of this research was quantitative method of correlation(correlation study) and approach cross sectional. The sampling technique was use Proportionate Stratified Random Sampling with a sample of 96 respondents, the processing unit and engineering unit at PT. Bisi International, Tbk., Tulungrejo Pare Kediri. The results of the research data were analyzed by ordinal regression test. The results of statistical analysis with ordinal regression showed that there was no relationship between knowledge, attitudes, actions of employees in the use of personal protective equipment (PPE) with the occurrence of work accidents at PT. Bisi International, Tbk., Tulungrejo Pare Kediri. The company must play an active role in giving awareness to employees about the importance of adhering to procedures and complying with the regulations in the use of personal protective equipment while working.
\end{abstract}

Received : March 12, 2019

Accepted: October 13, 2019

Published : November 26, 2019
Keywords : Knowledge, Attitude, Actions, Personal Protective Equipment, Work Accidents 


\section{INTRODUCTION}

Various changes and challenges in the world of industry and work lead to more competitive conditions and effective production processes are needed. Conditions like this certainly require better workforce activities, both quantity and quality, so that the goods and services produced will be beneficial to humans and will not cause adverse effects in the future. Especially for industries in the field of agriculture and food, the very rapid development now contributes positively to both the country and the community.

Every workplace always has a risk of work accidents. The amount of risk that occurs depends on the type of industry, technology and risk control efforts carried out. According Suma'mur (2009) in Sri Rejeki (2015) work accidents are accidents related to company activities, which means that accidents that occur due to work when doing a job and accidents that occur Work posture when traveling to and from work. PT. Bisi International, Tbk., Was established in Indonesia under the name PT. Bright Indonesia Seed Industry, is engaged in the trade sector in general, including exports, imports, wholesalers, suppliers and distributors / agents and / or retailers of all kinds of goods that can be traded, either directly or through third parties.

One of the causes of workplace accidents is the lack of awareness of the use of personal protective equipment at work. In the results of the researchers' preliminary survey conducted on November 22, 2017 researchers conducted field surveys, observations and interviews of 7 employees consisting of part packing processing units, sorting parts, seed mixing parts, civil engineering units, workshop parts, electrical parts and parts maintenance. Of the 7 employees interviewed, the engineering unit has used complete personal protective equipment, including safety shoes and safety helmets. When researchers asked about the benefits of personal protective equipment for civil engineering unit employees, the employee did not know exactly what the benefits were, only using personal protective equipment in accordance with the rules that apply in the company. In the processing unit, the sorting part that is supposed to use a mask, there are still employees who do not use masks for reasons of inconvenience at work. In addition to this in the part of the process that should use PPE in the form of masks, earplugs, gloves, only using a mask. The socialization of the use of PPE has not been fulfilled, so there are still workers who do not use PPE during the work. Whereas PPE that should be used in the processing unit is a helmet (safety helmet), ear plugs, masks, gloves and engineering units are helmets (safety helmet), masks, shoes (safety shoes), ear plugs, glasses, chemical gloves / non-chemical, safety harness, protective clothing. One of the efforts to prevent workplace accidents is to use PPE that meets the requirements, namely: comfortable in use, does not hinder the work process, and provides effective protection against types of hazards. Personal protective equipment is health equipment used by workers when in a dangerous workplace (Reason, 2007) in Putri (2014).

Looking at the conditions in the field as described above, the researchers are interested in doing "Analysis of Knowledge, Attitudes, Employee Actions in the Use of Personal Protective Equipment with Work Accidents at PT. Bisi International, Tbk., Tulungrejo Pare Kediri".

\section{MATERIALS AND METHODS}

The design of this research was quantitative method of correlation(correlation study)and approach, cross sectional where the process of data collection was done by distributing questionnaires simultaneously at the same time (Sugiyono, 2014). Data collection was carried out at PT. Bisi International, Tbk., Tulungrejo Pare-Kediri on 2 April to 4 May 2018.

The sample in this study were employees of the processing unit and engineering unit at PT. Bisi International, Tbk., Tulungrejo Pare-Kediri. Of the population as many as 127 people were selected as many as 96 people as samples taken by the technique Proportional Stratified Random Sampling.

The instruments used for data collection were questionnaires about knowledge, attitudes, actions in the use of personal protective equipment as well as work accidents that had been experienced by employees in a period of one year which was developed by the researchers themselves. The data that has been obtained then tested statistically by ordinal regression to analyze the relationship between the independent variable and the dependent variable. Where the independent variables in this study are knowledge, attitudes, actions in the use of personal protective equipment, while the dependent variable was work accidents. 


\section{RESULT}

Based on the results of research conducted from 2 April to 4 May 2018 on 96 respondents, the following results were obtained:

\section{CHARACTERISTICS OF RESEARCH VARIABLES}

Table 1: Distribution Frequency of Respondents based on Employee Knowledge of Personal Protective Equipment at PT. Bisi International, Tbk., Tulungrejo Pare Kediri, 2 April - 4 May 2018

\begin{tabular}{ccc}
\hline Knowledge & Frequency & \% \\
\hline Good & 55 & 57.3 \\
Enough & 40 & 41.7 \\
Less & 1 & 1 \\
\hline Total & 96 & 100 \\
\hline
\end{tabular}

The table shows that out of 96 respondents, the majority of respondents had 45 good knowledge people $(57.3 \%)$.

Table 2: Distribution Frequency of Respondents based on Employees' Attitudes to the Use of Personal Protective Equipment at PT. Bisi International, Tbk., Tulungrejo Pare Kediri, 2 April - 4 May 2018

\begin{tabular}{ccc}
\hline Attitude & Frequency & \% \\
\hline Good & 55 & 57.3 \\
Enough & 39 & 40.6 \\
Less & 2 & 2.1 \\
\hline Total & 96 & 100 \\
\hline
\end{tabular}

The table shows that out of 96 respondents, the majority of respondents with good attitude as many as 55 people $(57.3 \%)$.

Table 3: Distribution Frequency of Employee Actions in the Use of Personal Protective Equipment at PT. Bisi International Tbk., Tulungrejo Pare, 2 April - 4 May 2018

\begin{tabular}{ccc}
\hline Action & Frequency & \% \\
\hline Good & 62 & 64.6 \\
Enough & 19 & 19.8 \\
less & 15 & 15.6 \\
\hline Total & 96 & 100
\end{tabular}

The table shows that of the 96 respondents, most respondents to the level good action that is 62 people $(64.6 \%)$.

Table 4: Distribution Frequency of Employee Actions in the Use of Personal Protective Equipment at PT. Bisi International, Tbk., Tulungrejo Pare Kediri, 2 April - 4 May 2018

\begin{tabular}{ccc}
\hline Accidents & Frequency & \% \\
\hline High & 2 & 2.1 \\
Medium & 19 & 19.8 \\
Low & 75 & 78.1 \\
\hline Total & 96 & 100 \\
\hline
\end{tabular}

The table shows that out of 96 respondents, almost all respondents experienced an incident work accidents with a low category of 75 people $(78.1 \%)$. 
CROSS TABULATION BETWEEN INDEPENDENT VARIABLE AND DEPENDENT VARIABLE

Table 5: Cross Tabulation Between Knowledge of Respondents about Personal Protective Equipment with Work Accidents at PT. Bisi International, Tbk., Tulungrejo Pare Kediri dated 2 April-4 May 2018

\begin{tabular}{|c|c|c|c|c|c|c|}
\hline & & & \multicolumn{3}{|c|}{ Accidents } & \multirow{2}{*}{ Total } \\
\hline & & & High & Medium & Low & \\
\hline \multirow{6}{*}{ Knowledge } & \multirow{2}{*}{ Good } & $\sum$ & 1 & 5 & 49 & 55 \\
\hline & & $\%$ & 1 & 5,2 & 51 & 57,3 \\
\hline & \multirow{2}{*}{ Enough } & $\sum$ & 1 & 14 & 25 & 40 \\
\hline & & $\%$ & 1 & 14,6 & 26 & 41,7 \\
\hline & \multirow{2}{*}{ Less } & $\sum$ & 0 & 0 & 1 & 1 \\
\hline & & $\%$ & 0 & 0 & 1 & 1 \\
\hline \multirow{2}{*}{ Total } & & $\sum$ & 2 & 19 & 75 & 96 \\
\hline & & $\%$ & 2,1 & 19,8 & 78,1 & 100 \\
\hline
\end{tabular}

The table shows that out of 96 most respondents 49 people (51\%) had good knowledge and experienced accidents low category.

The table shows that out of 96 respondents most of the respondents were 44 people (45.8\%) with a good attitude and experienced a low category work accident.

Table 7: Cross Tabulation Between Respondents' Actions in the Use of Personal Protective Equipment With Work Accidents at PT. Bisi International, Tbk., Tulungrejo Pare Kediri dated 2 April-4 May 2018

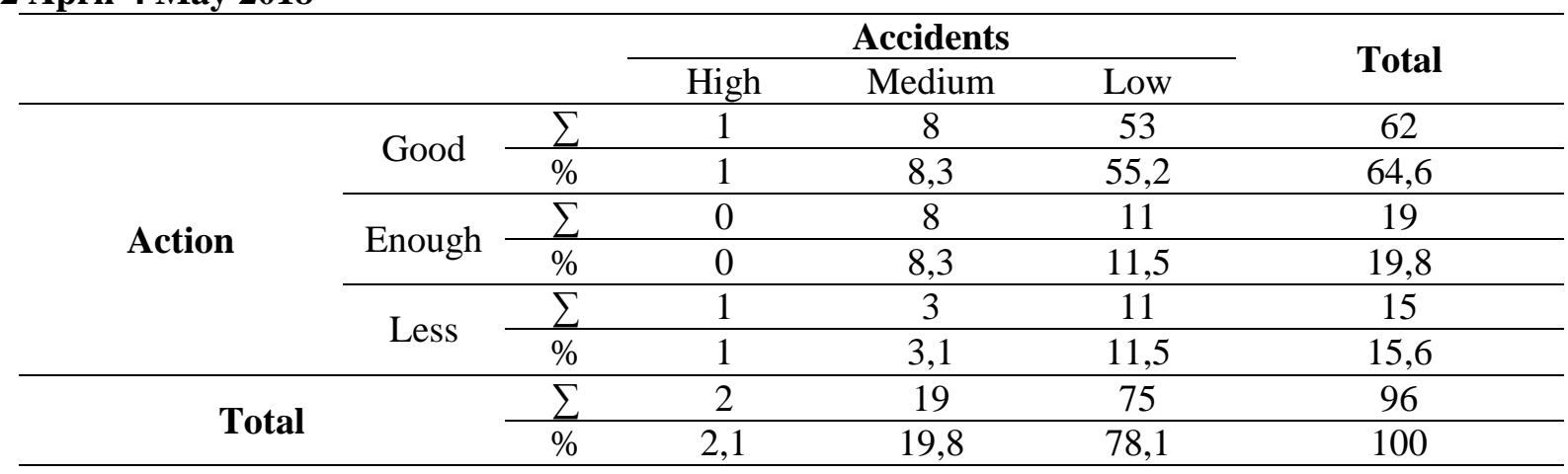

The table shows that out of 96 respondents most respondents 53 people (55.2\%) with good behavior experienced a low category accident.

\section{MULTIVARIATE ANALYSIS}

Statistical analysis used to prove or test the research hypothesis is ordinal regression. The results of ordinal regression analysis are as follows:

Table 8: Table Model Fitting Information Regression

\begin{tabular}{ccccc}
\hline Model & -2 Log Likelihood & Chi-Square & df & Sig. \\
\hline Intercept Only & 48,818 & & & \\
\hline Final & 37,231 & 11,588 & 5 &, 041 \\
\hline
\end{tabular}

\section{Ordinal}

The results of ordinal regression analysis showed the value of $p=0.041$, where $p 50.05$, which means that there is a significant relationship between knowledge, attitudes, and the use of personal protective equipment with work accidents. 
Table 9: Pseudo R-Square Regreasi Tables Default

Pseudo R-Square

\begin{tabular}{lr}
\hline Cox and Snell &, 114 \\
\hline Nagelkerke &, 164 \\
\hline McFadden &, 102 \\
\hline
\end{tabular}

The results of the analysis with ordinal regression, showed that the value of Nagelkerke $=0.164$ and Cox and Snell $=0.114$, which means that the diversity of data that can be explained by the ordinal regression model is $11.4 \%$ of all available data.

Table 10: Table Parameter Estimates Ordinal Regression Parameter Estimates

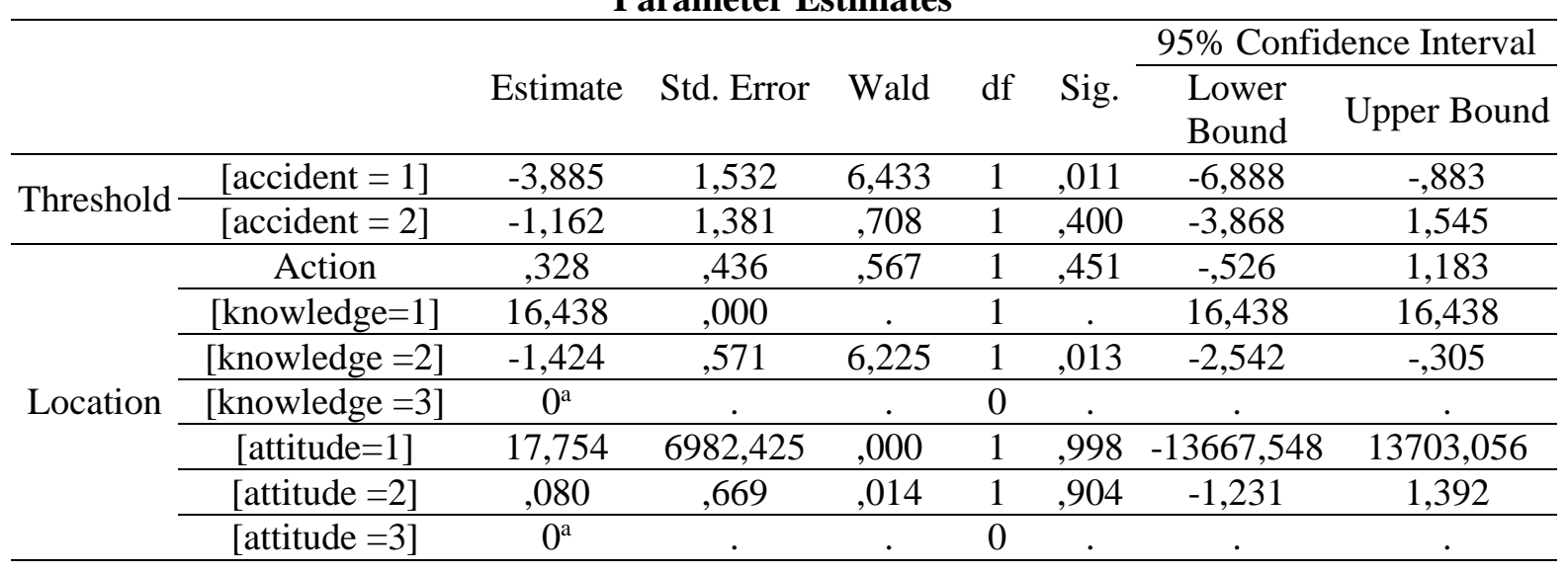

a. This parameter is set to zero because it is redundant.

The table shows that the variables associated with the occurrence of work accidents, with a weak relationship namely knowledge $(\mathrm{p}=0.013)$. While the action variable $(\mathrm{p}=0.451)$, and attitude $(\mathrm{p}$ $=0.998)$ means that actions and attitudes are not related to work accidents.

\section{DISCUSSION}

Correlation of Employee Knowledge in the Use of Personal Protective Equipment with Work Accidents at PT. Bisi International, Tbk., Tulungrejo Pare Kediri

Based on the results of this study shows that out of 96 respondents most of their knowledge about the use of personal protective equipment with the occurrence of good work accidents were 49 respondents $(51 \%)$ and experienced low category workplace accidents.

In the results of the questionnaire distributed to the respondents, there are some true and false questions about the knowledge of personal protective equipment with the most wrong answers, namely questions number 5, 14, and number 19. For the question number 5 face shield is the only eye and face protection tool. For question number 14, namely Safety shoes are only used to protect feet from sparks. As for question number 19 , namely by using protective clothing, ordinary clothes will be protected from sparks when welding. This shows that the respondent does not fully understand the functions and uses of each personal protective equipment that must be used when working.

The results of this study are in accordance with research conducted by Dian Putri Maharani and Anik Setyo Wahyuningsih (2017) which states that there is a significant relationship between knowledge and the use of personal protective equipment $(\mathrm{p}=0.006)$.

Most respondents do not understand the functions and uses of personal protective equipment that must be used at work. So that it is necessary to intervene from the company to play an active role in providing knowledge about personal protective equipment to employees by routinely providing direction and training on personal protective equipment both in terms of function, use, and impact produced when using and not using personal protective equipment. Respondents' knowledge of personal protective equipment is influenced by several factors, one of which is the experience at work, the conditions of the workplace and the direction given before working from the company. The Company must be more active in contributing to the awareness of employees that the risk of workplace accidents caused by the use of personal protective equipment is more harmful to the lives of employees, so that 
the employee's self-awareness will grow. It is not enough just with good knowledge, must be accompanied by good attitudes and actions in the use of personal protective equipment. Furthermore, employees who have high knowledge will be able to distinguish and know the dangers around them and can-do work in accordance with existing procedures because they are aware of the risks received, so that work accidents can be avoided. Employees who have high knowledge will try to avoid minor accidents because they are aware that minor accidents will cause more severe workplace accidents. If employees have good knowledge, they will act positively and try to avoid work accidents. Conversely employees who have low knowledge will tend to ignore the danger around it and do not do the work according to procedures because of ignorance of the risks that will be received. Employees who have less knowledge will tend to work at will and rush to get the job done quickly in order to save time and rest time faster. This is due to the ignorance and unconsciousness of employees of the importance of procedures and regulations in working to protect the employees themselves. Therefore, low employee knowledge will lead to more severe workplace accidents.

\section{Correlation of Employee Attitudes in the Use of Personal Protective Equipment with Work Accidents at PT. Bisi International, Tbk., Tulungrejo Pare Kediri}

Based on the results of this study indicate that of 96 respondents, most of the respondents were 44 people $(45.8 \%)$ with good attitude and experienced low category work accidents.

In the results of the questionnaires distributed to respondents, there were several questions that strongly disagreed, disagreed, agreed and strongly agreed about attitudes in the use of personal protective equipment with the most wrong answers, namely question number 7 and number 13. For question number 7 is I only use PPE if the company that provides the most answers is strongly disagree. For question number 13, that is, employees or workers do not need to do training on the proper use of PPE with the most answers is agree. This shows that the attitude of respondents who do not understand about the company that must provide personal protective equipment used at work and the importance of personal protective equipment that must be used at work, so respondents do not need training on the use of proper personal protective equipment.

The results of this study are consistent with the research conducted by Sihombing (2014) in Gladys Apriluana (2016), that there is no relationship between attitudes in the use of personal protective equipment and the occurrence of workplace accidents $(\mathrm{p}=0.058)$.

The attitude that is formed in the respondents related to the use of personal protective equipment is much influenced by personal experience, the influence of coworkers, education and length of work of the respondents. Attitudes are also influenced by coworkers; the more coworkers behave well in the use of personal protective equipment in their work has a lot of influence to behave the same in the use of personal protective equipment. So that companies must monitor and admonish employees more if they are negligent in using personal protective equipment while working so that the risk of accidents in work can be minimized. The company must play an active role in giving awareness to every employee that a good attitude in the use of personal protective equipment will affect good actions and knowledge, so that work accidents that occur can be avoided. Furthermore, employees who have a positive attitude will feel that the rules and procedures that have been implemented in the company are created and formed to protect and improve employee productivity. A good or positive attitude can lead to good behavior so that this attitude can prevent employees from occurring work accidents. On the contrary, employees who have less attitudes will tend to be unconcerned about the environment and the dangers around them. They will argue that the procedures and regulations for the use of personal protective equipment are only made for the benefit of the company and only burden employees and hamper performance. So that the employee is not able to prevent work accidents that occur.

\section{Correlation of Employee Actions in the Use of Personal Protective Equipment with Work Accidents at PT. Bisi International, Tbk., Tulungrejo Pare Kediri}

The results showed that from 96 respondents, the majority of respondents were 53 respondents (55.2\%) with good behavior having a low category work accident. From the results of the Ordinal Regression statistical test obtained $\mathrm{p}$ value $=0.451(\mathrm{p} \leq 0,005)$ which means that there is no significant relationship between actions in the use of personal protective equipment with the occurrence of work accidents at PT. Bisi International, Tbk., Tulungrejo Pare Kediri. This is not in accordance with the results of cross tabulation between actions and occurrence of work accidents. The better the action 
should be the lower the occurrence of work accidents and there is a significant relationship between action and workplace accidents. Factors that influence actions include attitudes of belief, motivational values and knowledge. Personal experience must give a strong impression to be able to be an attitude formation. Knowledge and attitude can influence the actions of respondents in the use of personal protective equipment to reduce the risk of workplace accidents that occur in the workplace according to Hombing (2015).

In the results of the questionnaire distributed to respondents, there were several questions with "yes" and "no" answers about the actions in the use of personal protective equipment with the most wrong answers, namely question number 6 and number 8 . For question number 6 is there are still workers who do not obeying the use of PPE when working with the most answers is yes. For question number 8 , I use gloves when working with the most answers is no. This shows that the actions of respondents who have not complied with the use of personal protective equipment at work and there are still employees who do not use personal protective equipment while working.

The results of this study are not in line with the research conducted by Lailatus Sa'adah (2017) which states that there is a significant relationship between the use of personal protective equipment and the incidence of workplace accidents $(\mathrm{p}=0.015)$. Likewise, with research conducted by Inna Nesyi Barizqi (2015) which states that there is a relationship between actions in the use of personal protective equipment and the occurrence of work accidents $(\mathrm{p}=0.011)$.

There are still employees who are still reluctant to use personal protective equipment while working, even though they already know the functions and uses of personal protective equipment. Factors that influence respondents include discomfort in using personal protective equipment. The inconvenience here is heat, weight, sweating or damp, pain, dizziness, tightness and so on. In addition, other reasons are disturbed by using personal protective equipment, often forgetting to use personal protective equipment, for example the use of masks and ear plugs, do not feel the need to use personal protective equipment even though they have often been reprimanded by the factory supervisor. Another reason is to feel that the work is not dangerous or does not affect its safety and health. Especially for employees who have done the work for years. Misunderstanding of the function of personal protective equipment due to lack of knowledge of the functions and uses of personal protective equipment, personal protective equipment interferes with the smoothness and speed of work is another reason employee who do not comply with regulations in using personal protective equipment. This is what can cause and increase the chances of minor work accidents and even severe work accidents. So that more explicit action is needed against employees who still do not use work protective equipment while working with verbal or written reprimands. So that it can create employees who are obedient and caring for work safety by using personal protective equipment while working.

\section{Identifying Work Accidents that Happened at PT. Bisi International, Tbk., Tulungrejo Pare Kediri}

PT. Bisi International, Tbk. Tulungrejo Pare Kediri consists of work units that have different types of work. Researchers conducted research on two units contained in the PT Hatchery Plant. Bisi International, Tbk., Tulungrejo Pare Kediri, namely the Processing Unit and Engineering Unit. The Processing Unit consists of packing parts, sorting parts and seed mixing parts. Whereas the Engineering Unit consists of civilian parts, workshops, electrical parts and maintenance parts.

This company is one place that has the potential danger of work accidents. Occupational accidents that have occurred in these two units, including in 2011 there were 1 work accident crash and 3 finger work accidents wedged conveyors to the processing unit employees, in 2015 there was 1 work accident in the processing unit ie the left index finger was hit by the cutter, in 2016 there was one accident when welding was done by an engineering unit employee who was exposed to a spark of welding into the shoe, causing panic and slipping, 1 work accident that happened to the employee in the processing unit when the toes were stuck in the sack thread causing injury torn in the middle of the toes, and 1 work accident that happened to the employees of the engineering unit when checking in the engine area and cleaning water that paint erupted and hit both employees' eyes.

Occupational accidents that occurred in 2017, including 1 incident of work accidents that occurred at the processing unit during the topping of the truck at the rear and the left foot slipped on the tarpaulin, so the driver fell down, 1 work accident in the engineering unit collapsed above the stairs as high as 1 , 5 meters, caused a fall and unconsciousness, 1 work accident in the form of a collision in the work area 
when driving a forklift, 1 work accident dropped from a truck when lowering the harvest but did not cause serious injury, 1 work accident that was unconscious in the area packing and 1 work accident that falls when pushing scrap.

Work accidents that occur at PT. Bisi International, Tbk., Tulungrejo is still categorized as low, so it makes employees still have a low awareness to use personal protective equipment while working.

\section{Correlation of Knowledge, Attitude, Action of Employees in the Use of Personal Protective Equipment with Work Accidents at PT. Bisi International, Tbk., Tulungrejo Pare Kediri}

From the results of research conducted that there is no significant relationship between knowledge, attitudes, actions and work accidents. Thus, the research hypothesis is not proven, namely there is no significant relationship between knowledge, attitudes, actions of employees in the use of personal protective equipment with work accidents at PT. Bisi International, Tbk., Tulungrejo Pare Kediri. And based on Pseudo R-Square ordinal regression is known that the values of Cox and Snell = 0.114 and Nagelkerke $=0.164$, which means that the diversity of data that can be explained by the ordinal regression model is $11.4 \%$ of all available data, and the ability of independent variables in explain the dependent variable is $16.4 \%$ and there are $72.2 \%$ other factors outside the model that explain the dependent variable.

Based on the Estimates Parameter of ordinal regression it is known that the variables associated with the occurrence of work accidents, from the relationship are knowledge about personal protective equipment. While the action variables in the use of personal protective equipment and attitudes in the use of personal protective equipment do not have a relationship with the occurrence of workplace accidents. Where the knowledge variable has a weak relationship with the occurrence of work accidents, namely $\mathrm{p}=0.013$.

According to Dewi Indah Siregar's research (2014) the way to develop attitudes / knowledge / skills needed by someone to carry out their duties or work adequately is to do regular training. The company has provided training and knowledge about personal protective equipment to all employees. However, it should be routinely checked as well as employees who have adhered to using personal protective equipment or not. In addition, the Company also requires more assertive action against employees who still do not use work protective equipment while working with verbal or written reprimands. So that it can create employees who are obedient and caring for work safety by using personal protective equipment while working. And provide rewards for employees who have complied with the regulations in the use of personal protective equipment at work, so that it can raise awareness for other employees to minimize the risk of workplace accidents. The company must play an active role in giving awareness to employees about the importance of complying with procedures and regulations for the use of personal protective equipment in the workplace. In addition, it is also supported by guidance and additional knowledge for employees and an assessment of the employee's knowledge, attitudes and actions so that there are still employees who do not have awareness of the importance of using personal protective equipment while working in order to create a conducive and avoidable work atmosphere. work accidents that can harm the employee himself and the company where he works.

\section{CONCLUSION}

There was no significant correlation between employee knowledge variables about personal protective equipment with work accidents, attitudes in the use of personal protective equipment and actions in the use of personal protective equipment with work accidents at PT. Bisi International, Tbk., Tulungrejo Pare Kediri.

\section{REFERENCES}

Apriluana, G., Khairiyati, L., \& Setyaningrum, R. (2016). Hubungan antara Usia, Jenis Kelamin, Lama Bekerja, Pengetahuan, Sikap dan Ketersediaan Alat Pelindung Diri (APD) dengan Perilaku Penggunaan APD pada Tenaga Kesehatan, Jurnal Publikasi Kesehatan Masyarakat Indonesia, Vol. 3 No. 3, diakses melalui Google Scholar pada tanggal 14 Nopember 2017 pukul. 09.56 wib. 
Hombing, \& WOC. (2015). Peningkatan Pengetahuan, Sikap dan Tindakan Remaja Laki-laki di SMK Negeri 4 Kecamatan Umbulharjo Kota Yogyakarta tentang Antibiotika dengan Metode CBIA (Cara Belajar Insan Aktif), Skripsi Fakultas Farmasi Universitas Yogyakarta, hal. 16-18.

Maharani, P., \& Wahyuningsih, A., S. (2017). Pengetahuan, Sikap, Kebijakan K3 dengan Penggunaan Alat Pelindung Diri di Bagian Ring Spinning Unit 1, Jurnal of Health Education, 33-38, http://journal.unnes.ac.id/sju/index.php/jhelathedu/, diakses melalui Google Scholar pada tanggal 13 Nopember 2017 pukul. 11.54 wib.

Putri, K., D., \& A., W., Denny, Y. (2014). Analisis Faktor yang Berhubungan dengan Kepatuhan Menggunakan Alat Pelindung Diri, The Indonesian Journal of Occupational Safety, Health and Environment, Vol. 1 No. 1: 24-36, diakses melalui Google Scholar pada tanggal 22 Januari 2018 pukul. 08.38 wib.

Rejeki, S. (2015). Sanitasi, Hygiene, dan Kesehatan \& Keselamatan Kerja (K3). Bandung: Rekayasa Sains.

Sa'adah, L. (2017). 'Hubungan Pemakaian Alat Pelindung Diri (APD) dengan Kejadian Kecelakaan Kerja pada Pekerja Penderes di PTPN III Kebun Sei Silau Tahun 2017', Skripsi, SKM., Fakultas Kesehatan Masyarakat, Universitas Negeri Sumatera Utara, Medan.

Siregar, \& Sari, D., I. (2014). 'Faktor-faktor yang Berhubungan dengan Kecelakaan Ringan di PT. Aqua Glden Mississippi Bekasi Tahun 2014', Skripsi, SKM., Fakultas Kesehatan Masyarakat, Universitas Islam Negeri Syarif Hidayatullah, Jakarta.

Sugiyono. (2014). Metode Penelitian Kuantitaif Kualitatif dan R\&D. CV. Alfabeta. Bandung. 